\title{
Correlation and path analysis of yield and its components and plant traits in wheat $^{1}$
}

\author{
Correlação e análise de trilha de rendimento e seus componentes e caracteres de planta em trigo
}

\author{
Lauro Akio Okuyama ${ }^{2} \quad$ Luiz Carlos Federizzi ${ }^{3} \quad$ José Fernandes Barbosa Neto $^{3}$
}

\begin{abstract}
This study was aimed to characterize yield components and plant traits related to grain yield. Correlation and path analysis were carried out in wheat genotypes grown under irrigated and non-irrigated field conditions. In the path coefficient analysis, grain yield represented the dependent variable and the number of spikes $m^{-2}$, number of grains spike $e^{-1}$, kernel weight, days to anthesis, above-ground biomass $m^{-2}$ and plant height were the independent ones. In both years, periods without rain occurred from early milk to grain ripening and from flag leaf sheath opening to grain ripening for first and second sowing dates, respectively. Character associations were similar in both water regimes. Grain yield showed positive phenotypic correlation with above-ground biomass, number of spikes $m^{-2}$ and number of grains per spike. Path analysis revealed positive direct effect and moderate correlation of number of spike $m^{-2}$ and number of grains per spike with grain yield. These results indicated that the number of spikes $m^{-2}$ and the number of grains per spike followed by the aboveground biomass were the traits related to higher grain yield, under irrigated and late season water stress conditions
\end{abstract}

Key words: Triticum aestivum, water stress, higher grain yield.

\section{RESUMO}

Este trabalho teve como objetivo avaliar os componentes de rendimento e os caracteres da planta relacionados ao rendimento de grãos. Análises de correlação e de trilha foram realizadas em genótipos de trigo cultivados no campo, sob condições irrigada e não-irrigada. Na análise de trilha, o rendimento de grãos $m^{-2}$ foi considerado como variável resposta e o número de espigas $m^{-2}$, número de grãos espiga ${ }^{-1}$, peso de grão, dias para antese, matéria seca da parte aérea e estatura de planta como variáveis explicativas. Períodos sem precipitação pluvial ocorreram em ambos os anos, do estádio de grão leitoso a maturação de grãos e do estádio da bainha da folha bandeira abrindo a maturação de grãos, para a primeira e segunda época de semeadura, respectivamente. As associações dos caracteres foram similares em ambos os regimes hídricos. O rendimento de grãos apresentou correlação fenotípica positiva com a matéria seca da parte aérea, o número de espigas $m^{-2}$ e o número de grãos espiga ${ }^{-1}$. A análise de trilha indicou efeito direto positivo e correlação moderada do número de espigas $m^{-2}$ e do número de grãos espiga ${ }^{-1}$ com o rendimento de grãos. Esses resultados evidenciaram que o numero de espigas $\mathrm{m}^{-2}$ e o número de grãos espiga $^{-1}$, seguido de matéria seca da parte aérea foram os caracteres relacionados com o maior rendimento de grãos, sob condições irrigada e de estresse hídrico no final do ciclo.

Palavras-chave: Triticum aestivum, estresse hídrico, maior rendimento de grãos.

\section{INTRODUCTION}

Water is the main abiotic limiting factor in many wheat production areas around the world. Due to erratic spatial and temporal distribution of rainfall, it is important to have cultivars with superior yield performance under limiting and non-limiting soil moisture conditions. Grain yield is the result of many developmental and physiological events occurring throughout the growing cycle. It is determined by three major components, namely, number of spikes per unit area, number of grains per spike and kernel weight. The importance of each one of these yield components to grain yield depends on the growth stage when water stress occurs (HOCHMAN, 1982; MCMASTER et al., 1984) and management (BLUE et al., 1990).

At jointing (stem extension), irrigation in dryland conditions affects yield components by increasing the number of spikes per plant, spikelet number per plant and number of kernels per plant, while at grain filling there is an increase in kernel weight (MCMASTER et al., 1984). The number of grains per spike is usually related to grain yield at all

\footnotetext{
${ }^{1}$ Extraído de parte da tese de doutorado do primeiro autor.

${ }^{2}$ Engenheiro Agrônomo, Doutor, Instituto Agronômico do Paraná (IAPAR), CP 481, 86001-970, Londrina, Paraná. E-mail: okuyama@iapar.br. Autor para correspondência.

${ }^{3}$ Engenheiro Agrônomo, PhD, Professor da Faculdade de Agronomia da Universidade Federal do Rio Grande do Sul, CP 776, 91501-970, Porto Alegre, Rio Grande do Sul.
} 
timings of water stress (SIMANE et al., 1993). Under conditions resulting in low tillering (late planting, low seeding rate, low $\mathrm{P}$ rate) kernel weight is extremely important to yield determination, while under high tillering conditions the number of spikes $\mathrm{m}^{-2}$ is the most important yield component (BLUE et al., 1990).

Wheat plant is more sensitive to water stress between booting and grain filling than any other period (FISCHER et al., 1977; HOCHMAN, 1982). On the other hand, it is more important to prevent water stress during tillering and jointing than during heading and grain filling period (THOMPSON \& CHASE, 1992). Yield components and plant trait contribution on grain yield may be important for breeding strategies. Simple correlation analysis that relates grain yield to a single variable may not provide a complete understanding of the importance of each component in determining grain yield (DEWEY \& LU, 1959; SINGH et al., 1979). Path coefficient analysis allows an effective means of partitioning correlation coefficients into unidirectional pathway and alternate pathways. This analysis permits a critical examination of specific factors that produce a given correlation and can be successfully employed in formulating an effective selection strategy. Through correlation and path coefficient analysis, KUMAR \& HUNSHAL (1998) observed in durum wheat that harvest index, total dry matter, effective tillers, number of grains per spike and grain weight per spike were the most important components of grain yield. With terminal moisture stress, longer grain-filling period, number of spikes $\mathrm{m}^{-2}$ and number of kernels per spike were traits associated with drought tolerance in durum wheat (SIMANE et al., 1998).

The objectives of this study were: (i) to evaluate associations between yield components and plant traits with grain yield, (ii) to determine direct and indirect effects of yield components and plant traits on grain yield in wheat genotypes grown under irrigated and non-irrigated conditions.

\section{MATERIAL AND METHODS}

Field experiments were conducted at the Esperimental Station of IAPAR (Instituto Agronômico do Paraná), in Londrina (latitude $23^{\circ} 23^{\prime} \mathrm{S}$, longitude $50^{\circ} 01^{\prime} \mathrm{W}$, altitude $556 \mathrm{~m}$ ). The soil is a Typic Haplorthox, characterized by a deep profile, fine texture, and very deep water table. Fertility is constrained by low organic matter and phosphorus contents. The region has a subtropical humid climate characterized by long hot summers and mild sunny winters. Experiments were sown in two planting dates, in 1994 and 1995. The field design for each sowing date was a split-plot arrangement of treatments within a randomized complete block with six replications. Water regimes, irrigated and nonirrigated (rainfed), were allocated to the main plots and cultivars to the subplots. Each subplot consisted of six rows with five meters in length, spaced $17 \mathrm{~cm}$ apart and seeded at a rate of 350 seed $\mathrm{m}^{-2}$.

The experiments included 10 spring wheat (Triticum aestivum L.) cultivars, one durum wheat (Triticum durum L.) and one triticale (X Tritosecale Wittimack). These materials represent a range of phenotypic variation in maturity, date to heading, height, adaptation zone, yield potential and date of release. Tillage of all plots was performed prior to each sowing date. Each year, before sowing, eight $\mathrm{kg}$ ha $^{-1}$ of $\mathrm{N}, 26 \mathrm{~kg} \mathrm{ha}^{-1}$ of $\mathrm{P}$ and $20 \mathrm{~kg} \mathrm{ha}^{-1}$ of $\mathrm{K}$ were broadcast on the surface and tilled into the soil. Around 25 days after plant emergence, $10 \mathrm{~kg} \mathrm{ha}^{-1}$ of $\mathrm{N}$ was applied through foliar spraying. Irrigation needs were controlled with tensiometers installed $30 \mathrm{~cm}$ depth, between the rows, and the plots were irrigated when the water tension was greater than $50 \mathrm{kPa}$. The major wheat diseases were spot blotch (Bipolaris sorokiniana), leaf rust (Puccinia recondita tritici) and powdery mildew (Erysiphe graminis) and were controlled by foliar spray with the fungicide tebuconazole. The number of days to anthesis, days to physiological maturity, plant height and lodging were recorded in each subplot. The values of above-ground biomass, kernel weight, number of spikes, number of grains per spike and grain yield was determined from 1 linear $\mathrm{m}$ sample obtained in each subplot. The number of days from emergence to anthesis was recorded when half of the heads in the plot shed pollen. The number of days to physiological maturity was estimated when $75 \%$ of the glumes of the primary spike turned yellow in $50 \%$ of the plants. Plant height was measured as the average distance from the soil surface to the tips of spikes, awns excluded. Lodging values were based on visual estimates of the percentage lodged straw in each subplot. Above-ground biomass $\mathrm{m}^{-2}$ was obtained by weighing an unthreshed bundle from $1 \mathrm{~m}$ row and a subsample of grain and straw were weighed and ovendried at $60^{\circ} \mathrm{C}$ for moisture correction. Individual kernel weight was estimated using a subsample of 300 kernels. Number of spikes $\mathrm{m}^{-2}$ was determined by counting spikes in $1 \mathrm{~m}$ of row. Number of grains per spike was determined by dividing grain yield by number of spikes and the result of this operation was divided by kernel weight, and grain yield was obtained 
by weighing the total grain weight of $1 \mathrm{~m}$ row, correcting the moisture to $13 \%$. Data were analyzed using analysis of variance and path coefficients procedure described by Genes (CRUZ, 1997). Path analysis was performed using genotypic correlation considering grain yield as the response variable and number of spike $\mathrm{m}^{-2}$, number of grains per spike, kernel weight, number of days to anthesis, aboveground biomass $\mathrm{m}^{-2}$ and plant height as predictor variables. To satisfy the assumption of additivity for the path-coefficient analysis, yield and yield component data were logarithmically transformed prior to analysis. Tests of significance of water treatments by $\mathrm{F}$ test and phenotypic correlation coefficients of yield and its components and plant traits by t-test were obtained through the Statistical Analysis System (SAS, 1990).

\section{RESULTS AND DISCUSSION}

Water shortage conditions allowed the comparisons of irrigated and non-irrigated treatments. The period without rain in 1994 ranged from 81 to 124 and 58 to 109 days after plant emergence for first and second sowing dates, respectively. In 1995, the period without rain ranged from 86 to 114 and 60 to 103 days after plant emergence for first and second sowing dates, respectively. In general, for both years, periods without rain occurred from early milk to grain ripening and from flag leaf sheath opening to grain ripening for first and second sowing dates, respectively. Rainfall water availability and irrigation plus precipitation on plants from sowing to grain maturity were respectively: $338,8 / 477,4 \mathrm{~mm}$ for first sowing of $1994,333,7 / 539,3 \mathrm{~mm}$ for second sowing of $1994,187,8 / 342,2 \mathrm{~mm}$ for first sowing of 1995 and $155,5 / 353,9 \mathrm{~mm}$ for second sowing of 1995 . Lower rainfall was observed in the second sowing date in 1995, when most of the water available to the plants was concentrated in the period from sowing to 35 days after emergence. Higher rainfall water availability was verified at the first sowing in 1994, when plenty of water was available from before sowing until early milk stage.

Increment of grain yield in irrigated water regime over non-irrigated treatments was verified in experiments conducted in 1994 (first and second sowing dates) and in 1995 second sowing date (Table 1). In the first sowing of 1995, grain yield was lower in the irrigated compared to the non-irrigated water regime, due to the higher lodging occurred in the irrigated treatment $(49.9 \%$ versus $9.2 \%)$. In the second sowing date of 1995, in spite of 44 days without rainfall (60 to 103 days after plant emergence) there were no apparent differences among water regimes. This probably was due to high water availability in the soil at the beginning of the period without rain, as well as the late sowing and higher temperature that decreased plant growth, as can be observed by the lower production of above-ground biomass (Table 1). Reduction in the length of the plant cycle under rainfed conditions is one of primary effects of the water deficit (THOMPSON \& CHASE, 1992), even when it occurs late in the season as observed in this study.

In both years, water stress in the first sowing was less severe than in the second sowing (Table 1). In the first sowing of 1994, there were significant differences among irrigated and nonirrigated water regimes for grain yield, kernel weight and number of days to anthesis. In the first sowing of 1995, all characters revealed significant differences. Positive effects of irrigation were observed for number of grains per spike, number of days to anthesis and plant height, while a negative effect was present for grain yield, number of spikes $\mathrm{m}^{-2}$, kernel weight and above-ground biomass. For the second sowing date, which had a longer period of water deficit, in 1994 all characters revealed significant differences among irrigated and non-irrigated water regimes, except for kernel weight. In 1995, the irrigated water regime was significantly superior to the non-irrigated for grain yield, number of days to anthesis and aboveground biomass. The other traits did not show any significant differences among water regimes.

The irrigated and non-irrigated water regimes presented similar phenotypic correlation (Tables 2 and 3). In general, grain yield correlated positively with number of spike $\mathrm{m}^{-2}$, number of grains per spike and above-ground biomass. The number of spikes $\mathrm{m}^{-2}$, correlated negatively with plant height, similarly as obtained by DEWEY \& LU (1959). According to these authors, high productivity of spikes in tall plants is difficult to be obtained. The number of grains per spike correlated negatively with kernel weight and positively with above-ground biomass and number of days to anthesis. The aboveground biomass correlated positively with grain yield. As this trait correlated positively with plant height, consequently, selection of taller plants leads to the largest amount of above-ground biomass. However, as higher plants present smaller number of spikes $\mathrm{m}^{-2}$ and higher lodging, the choice of taller plants with larger above-ground biomass may not increase grain yield.

Ciência Rural, v.34, n.6, nov-dez, 2004. 
Table 1 - Biometrical and phenological characters of wheat genotypes under irrigated (I) and non-irrigated (NI) conditions.

\begin{tabular}{|c|c|c|c|c|c|c|c|c|c|}
\hline \multicolumn{3}{|c|}{ Experiment } & \multirow[b]{2}{*}{$\begin{array}{l}\text { Grain yield } \\
\quad\left(\mathrm{gm}^{-2}\right)\end{array}$} & \multirow[b]{2}{*}{$\begin{array}{l}\text { No. of spikes } \\
\mathrm{m}^{-2}\end{array}$} & \multirow[b]{2}{*}{$\begin{array}{l}\mathrm{N}^{\mathrm{o}} \text {. of grains } \\
\text { per spike }\end{array}$} & \multirow[b]{2}{*}{$\begin{array}{l}\text { Kernel weight } \\
(\mathrm{mg})\end{array}$} & \multirow[b]{2}{*}{$\begin{array}{l}\text { Days to } \\
\text { anthesis }\end{array}$} & \multirow[b]{2}{*}{$\begin{array}{l}\text { Above-ground } \\
\text { biomass }\left(\mathrm{gm}^{-2}\right)\end{array}$} & \multirow[b]{2}{*}{$\begin{array}{l}\text { Plant height } \\
\quad(\mathrm{cm})\end{array}$} \\
\hline Year & Sowing & $\begin{array}{l}\text { Water } \\
\text { regime }\end{array}$ & & & & & & & \\
\hline 1994 & $1^{\mathrm{st}}$ & I & $458.0 \mathrm{a}^{1}$ & $361.0 \mathrm{a}$ & $37.0 \mathrm{a}$ & $35.9 \mathrm{a}$ & $78.5 \mathrm{a}$ & $1011.4 \mathrm{a}$ & $82.4 \mathrm{a}$ \\
\hline 1994 & $1^{\mathrm{st}}$ & NI & $431.8 \mathrm{~b}$ & $346.5 \mathrm{a}$ & $37.2 \mathrm{a}$ & $34.8 \mathrm{~b}$ & $76.9 \mathrm{~b}$ & 961.6 a & $83.5 \mathrm{a}$ \\
\hline 1994 & $2^{\text {nd }}$ & I & $432.5 \mathrm{a}$ & $385.7 \mathrm{a}$ & $39.9 \mathrm{a}$ & $29.1 \mathrm{a}$ & $80.9 \mathrm{a}$ & $999.3 \mathrm{a}$ & $85.1 \mathrm{a}$ \\
\hline 1994 & $2^{\text {nd }}$ & NI & $329.0 \mathrm{~b}$ & $319.3 \mathrm{~b}$ & $37.7 \mathrm{~b}$ & $27.9 \mathrm{a}$ & $77.5 \mathrm{~b}$ & $756.8 \mathrm{~b}$ & $80.8 \mathrm{~b}$ \\
\hline 1995 & $1^{\mathrm{st}}$ & I & $304.4 \mathrm{~b}$ & $266.4 \mathrm{~b}$ & $37.6 \mathrm{a}$ & $31.4 \mathrm{~b}$ & $74.6 \mathrm{a}$ & $749.6 \mathrm{~b}$ & $84.8 \mathrm{a}$ \\
\hline 1995 & $1^{\mathrm{st}}$ & NI & 434.9 a & 380.9 a & $31.6 \mathrm{~b}$ & $37.2 \mathrm{a}$ & $69.8 \mathrm{~b}$ & $921.0 \mathrm{a}$ & $80.4 \mathrm{~b}$ \\
\hline 1995 & $2^{\text {nd }}$ & I & $277.7 \mathrm{a}$ & $317.1 \mathrm{a}$ & $37.0 \mathrm{a}$ & $24.5 \mathrm{a}$ & $70.4 \mathrm{a}$ & $763.8 \mathrm{a}$ & $85.2 \mathrm{a}$ \\
\hline 1995 & $2^{\text {nd }}$ & NI & $243.3 \mathrm{~b}$ & $299.5 \mathrm{a}$ & $34.9 \mathrm{a}$ & $24.0 \mathrm{a}$ & $69.8 \mathrm{~b}$ & $690.9 \mathrm{~b}$ & $83.3 \mathrm{a}$ \\
\hline
\end{tabular}

${ }^{1}$ For sowing period, means within the same column followed by same letter are not significantly different at 0.05 probability level by $\mathrm{F}$ test.

Table 2 - Phenotypic correlation coefficients among grain yield, yield components, and plant traits of wheat genotypes under irrigated field condition.

\begin{tabular}{|c|c|c|c|c|c|c|c|c|}
\hline Year & Sowing & Trait & № . of spikes $\mathrm{m}^{-2}$ & $\begin{array}{l}\mathrm{N}^{\mathrm{o}} \text {. of grains } \\
\text { perspike }\end{array}$ & $\begin{array}{l}\text { Kernel weight } \\
\text { (mg) }\end{array}$ & $\begin{array}{l}\text { Days to } \\
\text { anthesis }\end{array}$ & $\begin{array}{l}\text { Above-ground } \\
\text { biomass }\left(\mathrm{gm}^{-2}\right)\end{array}$ & $\begin{array}{l}\text { Plant height } \\
(\mathrm{cm})\end{array}$ \\
\hline 1994 & $1^{\mathrm{st}}$ & Grain & $0.126 \mathrm{~ns}$ & $0.811 * *$ & -0.169 & $0.692 *$ & $0.845 * *$ & 0.058 \\
\hline 1994 & $2^{\text {nd }}$ & yield & 0.520 & 0.168 & -0.004 & -0.548 & 0.384 & -0.294 \\
\hline 1995 & $1^{\mathrm{st}}$ & $\left(\mathrm{gm}^{2}\right)$ & $0.595 *$ & $0.750 * *$ & $-0.695 *$ & 0.306 & $0.649 *$ & -0.139 \\
\hline 1995 & $2^{\text {nd }}$ & & $0.650 *$ & -0.164 & 0.207 & -0.563 & $0.742 * *$ & -0.039 \\
\hline 1994 & $1^{\mathrm{st}}$ & $\mathrm{N}^{\mathrm{o}}$. of & & -0.123 & -0.325 & -0.154 & -0.074 & $-0.721 * *$ \\
\hline 1994 & $2^{\text {nd }}$ & spikes $\mathrm{m}^{-2}$ & & -0.074 & -0.486 & -0.313 & 0.134 & $-0.634 *$ \\
\hline 1995 & $1^{\mathrm{st}}$ & & & 0.070 & $-0.594 *$ & -0.363 & -0.039 & $-0.589 *$ \\
\hline 1995 & $2^{\text {nd }}$ & & & -0.427 & -0.236 & -0.501 & 0.405 & -0.519 \\
\hline 1994 & $1^{\text {st }}$ & $\mathrm{N}^{\mathrm{o}}$. of & & & -0.572 & $0.617 *$ & $0.768 * *$ & 0.160 \\
\hline 1994 & $2^{\text {nd }}$ & grains per spike & & & $-0.690 *$ & 0.459 & $0.603 *$ & 0.052 \\
\hline 1995 & $1^{\mathrm{st}}$ & & & & $-0.735 * *$ & $0.709 * *$ & $0.672 *$ & 0.061 \\
\hline 1995 & $2^{\text {nd }}$ & & & & $-0.586 *$ & 0.474 & -0.449 & -0.213 \\
\hline 1994 & $1^{\mathrm{st}}$ & Kernel & & & & -0.042 & -0.165 & 0.308 \\
\hline 1994 & $2^{\text {nd }}$ & weight (mg) & & & & -0.444 & -0.411 & 0.326 \\
\hline 1995 & $1^{\mathrm{st}}$ & & & & & -0.297 & -0.234 & 0.427 \\
\hline 1995 & $2^{\text {nd }}$ & & & & & -0.322 & 0.555 & $0.778 * *$ \\
\hline 1994 & $1^{\mathrm{st}}$ & Days to & & & & & $0.751 * *$ & 0.394 \\
\hline 1994 & $2^{\text {nd }}$ & anthesis & & & & & 0.362 & 0.181 \\
\hline 1995 & $1^{\mathrm{st}}$ & & & & & & 0.528 & 0.244 \\
\hline 1995 & $2^{\text {nd }}$ & & & & & & -0.281 & -0.018 \\
\hline 1994 & $1^{\mathrm{st}}$ & Above-ground & & & & & & 0.384 \\
\hline 1994 & $2^{\text {nd }}$ & biomass & & & & & & 0.369 \\
\hline 1995 & $1^{\text {st }}$ & $\left(\mathrm{gm}^{-2}\right)$ & & & & & & $0.598 *$ \\
\hline 1995 & $2^{\text {nd }}$ & & & & & & & 0.393 \\
\hline
\end{tabular}

$*$ and $* *$ significant at 0.05 and 0.01 probability levels by $\mathrm{t}$ test, respectively. $\mathrm{ns}=$ not significant $(\mathrm{P}>0.05)$.

Ciência Rural, v.34, n.6, nov-dez, 2004. 
Table 3 - Phenotypic correlation coefficients among grain yield, yield components, and plant traits of wheat genotypes under non-irrigated field condition.

\begin{tabular}{|c|c|c|c|c|c|c|c|c|}
\hline Year & Sowing & Trait & $\begin{array}{c}\text { No. of } \\
\text { spikes } \mathrm{m}^{-2}\end{array}$ & $\begin{array}{l}\text { No. of grains per } \\
\text { spike }\end{array}$ & $\begin{array}{l}\text { Kernel weight } \\
\text { (mg) }\end{array}$ & $\begin{array}{l}\text { Days to } \\
\text { anthesis }\end{array}$ & $\begin{array}{l}\text { Above-ground } \\
\text { biomass }\left(\mathrm{gm}^{-2}\right)\end{array}$ & Plant height $(\mathrm{cm})$ \\
\hline 1994 & $1^{\mathrm{st}}$ & Grain & $0.441 \mathrm{~ns}$ & $0.826 * *$ & -0.301 & $0.601 *$ & $0.853 * *$ & 0.012 \\
\hline 1994 & $2^{\text {nd }}$ & yield & 0.505 & 0.422 & 0.144 & -0.070 & $0.899 * *$ & 0.172 \\
\hline 1995 & $1^{\text {st }}$ & $\left(\mathrm{gm}^{-2}\right)$ & 0.465 & 0.546 & -0.563 & -0.018 & $0.591 *$ & -0.245 \\
\hline 1995 & $2^{\text {nd }}$ & & $0.626 *$ & 0.063 & -0.043 & $-0.639 *$ & $0.831 * *$ & -0.228 \\
\hline 1994 & $1^{\text {st }}$ & No. of & & 0.092 & -0.466 & -0.115 & 0.285 & $-0.763 * *$ \\
\hline 1994 & $2^{\text {nd }}$ & spikes $\mathrm{m}^{-2}$ & & -0.118 & -0.214 & -0.554 & 0.246 & -0.450 \\
\hline 1995 & $1^{\text {st }}$ & & & -0.326 & -0.493 & $-0.583^{*}$ & 0.004 & $-0.826 * *$ \\
\hline 1995 & $2^{\text {nd }}$ & & & -0.343 & -0.462 & -0.557 & 0.359 & $-0.679 *$ \\
\hline 1994 & $1^{\text {st }}$ & No. of & & & -0.553 & $0.627 *$ & $0.791 * *$ & 0.267 \\
\hline 1994 & $2^{\text {nd }}$ & grains per spike & & & $-0.577 *$ & 0.390 & 0.464 & 0.067 \\
\hline 1995 & $1^{\text {st }}$ & & & & -0.546 & 0.557 & 0.512 & 0.366 \\
\hline 1995 & $2^{\text {nd }}$ & & & & -0.449 & 0.523 & 0.024 & -0.027 \\
\hline 1994 & $1^{\text {st }}$ & Kernel & & & & -0.027 & -0.324 & 0.320 \\
\hline 1994 & $2^{\text {nd }}$ & weight (mg) & & & & -0.025 & 0.218 & 0.508 \\
\hline 1995 & $1^{\mathrm{st}}$ & & & & & -0.032 & -0.240 & 0.390 \\
\hline 1995 & $2^{\text {nd }}$ & & & & & -0.303 & 0.205 & $0.728 * *$ \\
\hline 1994 & $1^{\text {st }}$ & Days to & & & & & 0.529 & 0.368 \\
\hline 1994 & $2^{\text {nd }}$ & anthesis & & & & & 0.247 & 0.166 \\
\hline 1995 & $1^{\text {st }}$ & & & & & & -0.072 & 0.242 \\
\hline 1995 & $2^{\text {nd }}$ & & & & & & -0.441 & 0.009 \\
\hline 1994 & $1^{\mathrm{st}}$ & Above-ground & & & & & & 0.227 \\
\hline 1994 & $2^{\text {nd }}$ & biomass & & & & & & 0.428 \\
\hline 1995 & $1^{\mathrm{st}}$ & $\left(\mathrm{gm}^{-2}\right)$ & & & & & & 0.406 \\
\hline 1995 & $2^{\text {nd }}$ & & & & & & & 0.157 \\
\hline
\end{tabular}

* and ** significant at 0.05 and 0.01 probability levels by t test, respectively. $\mathrm{ns}=$ not significant $(\mathrm{P}>0.05)$

In irrigated and non-irrigated water regimes, the direct effects of the number of spikes $\mathrm{m}^{-2}$ and number of grains per spike on grain yield were positive and of high magnitude and the total correlation coefficients of grain yield with number of spike $\mathrm{m}^{-2}$ and number of grains per spike were positive and of intermediate value (Tables 4 and 5). In these cases, direct selection for higher number of spike $\mathrm{m}^{-2}$ and/or larger number of grains per spike would be enough to increase grain yield. These results are similar to those obtained by SHAMSUDDIN (1987), SIMANE et al. (1998), and DEL BLANCO et al. (2001). Kernel weight had high positive direct effect on yield that was nullified by the negative indirect effects of number of grains per spike and number of spikes $\mathrm{m}^{-2}$, resulting in low or insignificant negative total correlations. Association studies between kernel weight and grain yield indicated a tendency of kernel weight to decrease with increasing of number of spikes $\mathrm{m}^{-2}$ and number of grains per spike. Similar result was also verified by SIDWELL et al. (1976), where negative associations were verified between kernel weight and tiller number, and between kernel weight and number of grains per spike. The direct effect of number of days to anthesis and plant height on grain yield was negative or close to zero, and the total correlation between these traits and grain yields were of small magnitude. This is an indication that these two traits had small effect on grain yield. The direct ground biomass had negligible direct effects on grain yield in spite of positive correlation coeficients, which occurred mainly due to the positive indirect effect of number of grains per spike.

A more detailed study of the relationships obtained by path analysis showed that the relation between grain yield and its components and plant traits are somewhat different from that presented in the simple analysis of correlation. In the correlation study, the aboveground biomass was the main plant trait related to grain yield increase, while in the path analysis its importance was secondary. The apparent divergence is due to the analytical approach. While correlation simply identifies the mutual associations among the parameters, path analysis allows determination of the relative magnitude of each effect. When the objective is to establish relationships among the variables that affect grain yield, path coefficient analysis is a more efficient method than the correlation analysis (DEWEY \& LU, 1959). Thus, the results reported in this paper show that number of spikes $\mathrm{m}^{-2}$ and number of grains per spike, followed by aboveground biomass $\mathrm{m}^{-2}$ should be considered as selection criteria for wheat yield improvement. 
Table 4 - Direct and indirect effects of factors influencing grain yield in wheat genotypes under irrigated field conditions.

\begin{tabular}{|c|c|c|c|c|c|}
\hline \multirow{2}{*}{ Patway of association } & \multicolumn{2}{|c|}{$1^{\text {st }}$ sowing } & \multicolumn{2}{|c|}{$2^{\text {nd }}$ sowing } & \multirow{2}{*}{ Average } \\
\hline & 1994 & 1995 & 1994 & 1995 & \\
\hline \multicolumn{6}{|l|}{ Yield vs. number of spikes $\mathrm{m}^{-2}$} \\
\hline Direct effect & 0.472 & 1.307 & 2.906 & 1.419 & 1.526 \\
\hline Indirect effect via number of grains per spike & -0.138 & 0.123 & -0.234 & -0.523 & -0.193 \\
\hline via kernel weight & -0.277 & -0.932 & -2.030 & -0.312 & -0.888 \\
\hline via days to anthesis & 0.004 & -0.005 & -0.126 & 0.027 & -0.025 \\
\hline via above-ground biomass & -0.019 & 0.003 & -0.029 & 0.038 & -0.002 \\
\hline via plant height & 0.009 & -0.002 & 0.014 & 0.026 & 0.012 \\
\hline Total correlation & 0.051 & 0.494 & 0.502 & 0.675 & 0.430 \\
\hline \multicolumn{6}{|l|}{ Yield vs. number of grains per spike } \\
\hline Direct effect & 1.275 & 1.847 & 2.728 & 1.194 & 1.761 \\
\hline Indirect effect via number of spikes $\mathrm{m}^{-2}$ & -0.051 & 0.087 & -0.249 & -0.622 & -0.209 \\
\hline via kernel weight & -0.433 & -1.036 & -2.821 & -0.776 & -1.266 \\
\hline via days to anthesis & -0.013 & 0.009 & 0.193 & -0.026 & 0.041 \\
\hline via above-ground biomass & 0.060 & -0.004 & 0.129 & -0.065 & 0.030 \\
\hline via plant height & -0.002 & 0.000 & -0.001 & 0.011 & 0.002 \\
\hline Total correlation & 0.835 & 0.903 & -0.022 & -0.283 & 0.358 \\
\hline \multicolumn{6}{|l|}{ Yield vs. kernel weight } \\
\hline Direct effect & 0.750 & 1.347 & 3.824 & 1.258 & 1.795 \\
\hline Indirect effect via number of spikes $\mathrm{m}^{-2}$ & -0.175 & -0.903 & -1.542 & -0.352 & -0.743 \\
\hline via number of grains per spike & -0.736 & -1.420 & -2.012 & -0.737 & -1.226 \\
\hline via days to anthesis & 0.001 & -0.004 & -0.173 & 0.017 & -0.040 \\
\hline via above-ground biomass & -0.013 & 0.002 & -0.100 & 0.068 & -0.011 \\
\hline via plant height & -0.003 & 0.001 & -0.007 & -0.038 & -0.012 \\
\hline Total correlation & -0.177 & -0.977 & -0.009 & 0.216 & -0.237 \\
\hline \multicolumn{6}{|l|}{ Yield vs. number of days to anthesis } \\
\hline Direct effect & -0.022 & 0.012 & 0.382 & -0.051 & 0.080 \\
\hline Indirect effect via number of spikes $\mathrm{m}^{-2}$ & -0.081 & -0.551 & -0.957 & -0.750 & -0.585 \\
\hline via number of grains per spike & 0.796 & 1.349 & 1.379 & 0.608 & 1.033 \\
\hline via kernel weight & -0.031 & -0.405 & -1.734 & -0.411 & -0.645 \\
\hline via above-ground biomass & 0.059 & -0.004 & 0.096 & -0.037 & 0.029 \\
\hline via plant height & -0.004 & 0.001 & -0.004 & 0.001 & -0.002 \\
\hline Total correlation & 0.718 & 0.403 & -0.838 & -0.641 & -0.090 \\
\hline \multicolumn{6}{|l|}{ Yield vs. above-ground biomass } \\
\hline Direct effect & 0.071 & -0.005 & 0.177 & 0.102 & 0.086 \\
\hline Indirect effect via number of spikes $\mathrm{m}^{-2}$ & -0.126 & -0.798 & -0.479 & 0.523 & -0.220 \\
\hline via number of grains per spike & 1.071 & 1.664 & 1.988 & -0.758 & 0.991 \\
\hline via kernel weight & -0.138 & -0.492 & -2.157 & 0.838 & -0.487 \\
\hline via number of days to anthesis & -0.018 & 0.010 & 0.207 & 0.018 & 0.054 \\
\hline via plant height & -0.005 & 0.002 & -0.011 & -0.022 & -0.009 \\
\hline Total correlation & 0.857 & 0.381 & -0.275 & 0.702 & 0.416 \\
\hline \multicolumn{6}{|l|}{ Yield vs. plant height } \\
\hline Direct effect & -0.011 & 0.003 & -0.020 & -0.048 & -0.019 \\
\hline Indirect effect via number of spikes $\mathrm{m}^{-2}$ & -0.401 & -0.917 & -2.038 & -0.782 & -1.034 \\
\hline via number of grains per spike & 0.210 & 0.102 & 0.167 & -0.275 & 0.051 \\
\hline via kernel weight & 0.234 & 0.582 & 1.273 & 0.993 & 0.770 \\
\hline via number of days to anthesis & -0.009 & 0.003 & 0.068 & 0.001 & 0.016 \\
\hline via above-ground biomass & 0.029 & -0.004 & 0.092 & 0.047 & 0.041 \\
\hline Total correlation & 0.053 & -0.232 & -0.459 & -0.064 & -0.175 \\
\hline Coefficient of determination & 1.000 & 0.999 & 1.000 & 1.000 & 1.000 \\
\hline Residual & 0.000 & 0.034 & 0.000 & 0.017 & 0.013 \\
\hline
\end{tabular}

Ciência Rural, v.34, n.6, nov-dez, 2004. 
Table 5. Direct and indirect effects of factors influencing grain yield in wheat genotypes under non-irrigated field conditions.

\begin{tabular}{|c|c|c|c|c|c|}
\hline \multirow{2}{*}{ Patway of association } & \multicolumn{2}{|c|}{$1^{\text {st }}$ sowing } & \multicolumn{2}{|c|}{$2^{\text {nd }}$ sowing } & \multirow{2}{*}{ Average } \\
\hline & 1994 & 1995 & 1994 & 1995 & \\
\hline \multicolumn{6}{|l|}{ Yield vs. number of spikes $\mathrm{m}^{-2}$} \\
\hline Direct effect & 0.586 & 1.879 & 0.897 & 1.553 & 1.229 \\
\hline Indirect effect via number of grains per spike & 0.135 & -0.782 & -0.151 & -0.460 & -0.315 \\
\hline via kernel weight & -0.300 & -0.793 & -0.288 & -0.599 & -0.495 \\
\hline via days to anthesis & -0.001 & 0.019 & -0.033 & 0.085 & 0.018 \\
\hline via above-ground biomass & 0.005 & -0.011 & -0.004 & 0.014 & 0.001 \\
\hline via plant height & -0.002 & 0.077 & -0.026 & 0.050 & 0.025 \\
\hline Total correlation & 0.424 & 0.389 & 0.395 & 0.642 & 0.463 \\
\hline \multicolumn{6}{|l|}{ Yield vs. number of grains per spike } \\
\hline Direct effect & 1.072 & 2.182 & 1.271 & 1.189 & 1.428 \\
\hline Indirect effect via number of spikes $\mathrm{m}^{-2}$ & 0.074 & -0.674 & -0.107 & -0.601 & -0.327 \\
\hline via kernel weight & -0.338 & -0.813 & -0.726 & -0.571 & -0.612 \\
\hline via days to anthesis & 0.003 & -0.018 & 0.021 & -0.081 & -0.019 \\
\hline via above-ground biomass & 0.033 & 0.021 & -0.042 & -0.007 & 0.001 \\
\hline via plant height & 0.000 & -0.033 & 0.003 & 0.003 & -0.007 \\
\hline Total correlation & 0.844 & 0.666 & 0.420 & -0.067 & 0.466 \\
\hline \multicolumn{6}{|l|}{ Yield vs. kernel weight } \\
\hline Direct effect & 0.599 & 1.452 & 1.166 & 1.225 & 1.111 \\
\hline Indirect effect via number of spikes $\mathrm{m}^{-2}$ & -0.293 & -1.027 & -0.221 & -0.759 & -0.575 \\
\hline via number of grains per spike & -0.606 & -1.221 & -0.790 & -0.554 & -0.793 \\
\hline via days to anthesis & 0.000 & 0.001 & -0.001 & 0.044 & 0.011 \\
\hline via above-ground biomass & -0.013 & -0.013 & -0.022 & 0.018 & -0.008 \\
\hline via plant height & 0.001 & -0.034 & 0.024 & -0.052 & -0.016 \\
\hline Total correlation & -0.313 & -0.843 & 0.156 & -0.078 & -0.270 \\
\hline \multicolumn{6}{|l|}{ Yield vs. number of days to anthesis } \\
\hline Direct effect & 0.005 & -0.031 & 0.050 & -0.145 & -0.030 \\
\hline Indirect effect via number of spikes $\mathrm{m}^{-2}$ & -0.068 & -1.151 & -0.598 & -0.910 & -0.682 \\
\hline via number of grains per spike & 0.691 & 1.249 & 0.524 & 0.665 & 0.782 \\
\hline via kernel weight & -0.016 & -0.045 & -0.027 & -0.376 & -0.116 \\
\hline via above-ground biomass & 0.022 & -0.003 & -0.026 & -0.035 & -0.010 \\
\hline via plant height & 0.001 & -0.021 & 0.008 & -0.001 & -0.003 \\
\hline Total correlation & 0.634 & -0.003 & -0.070 & -0.801 & -0.060 \\
\hline \multicolumn{6}{|l|}{ Yield vs. above-ground biomass } \\
\hline Direct effect & 0.035 & 0.028 & -0.087 & 0.050 & 0.006 \\
\hline Indirect effect via number of spikes $\mathrm{m}^{-2}$ & 0.088 & -0.725 & 0.039 & 0.435 & -0.041 \\
\hline via number of grains per spike & 1.010 & 1.622 & 0.613 & -0.170 & 0.769 \\
\hline via kernel weight & -0.225 & -0.690 & 0.296 & 0.447 & -0.043 \\
\hline via number of days to anthesis & 0.003 & 0.003 & 0.015 & 0.101 & 0.030 \\
\hline via plant height & 0.000 & -0.056 & 0.023 & -0.015 & -0.012 \\
\hline Total correlation & 0.910 & 0.183 & 0.898 & 0.847 & 0.710 \\
\hline \multicolumn{6}{|l|}{ Yield vs. plant height } \\
\hline Direct effect & 0.002 & -0.087 & 0.047 & -0.070 & -0.027 \\
\hline Indirect effect via number of spikes $\mathrm{m}^{-2}$ & -0.491 & -1.663 & -0.500 & -1.112 & -0.942 \\
\hline via number of grains per spike & 0.291 & 0.813 & 0.095 & -0.043 & 0.289 \\
\hline via kernel weight & 0.193 & 0.572 & 0.605 & 0.918 & 0.572 \\
\hline via number of days to anthesis & 0.002 & -0.008 & 0.008 & 0.001 & 0.001 \\
\hline via above-ground biomass & 0.009 & 0.018 & -0.044 & 0.011 & -0.001 \\
\hline Total correlation & 0.005 & -0.355 & 0.210 & -0.295 & -0.109 \\
\hline Coefficient of determination & 0.999 & 0.997 & 0.998 & 1.000 & 0.998 \\
\hline Residual & 0.024 & 0.058 & 0.043 & 0.013 & 0.034 \\
\hline
\end{tabular}

Ciência Rural, v.34, n.6, nov-dez, 2004. 


\section{REFERENCES}

BLUE, E.N. et al. Influence of planting date, seeding rate, and phosphorus rate on wheat yield. Agronomy Journal, Madison. v.82, n.4, p.762-768, 1990 .

CRUZ, C.D. Programa genes: aplicativo computacional em genética e estatística. Viçosa : UFV, 1997. 442p.

DEL BLANCO, I.A. et al. Agronomic potential of synthetic hexaploid wheat-derived populations. Crop Science, Madison, v.41, n.3, p.670-676, 2001.

DEWEY, D.R.; LU, K.H. A correlation and path-coefficient analysis of components of crested wheatgrass seed production. Agronomy Journal, Madison, v.51, n.8, p.515$518,1959$.

FISCHER, R.A. et al. Irrigation of dwarf wheats in the Yaqui Valley of Mexico. Experimental Agriculture, New York, v.13, n.4, p.353-367, 1977.

HOCHMAN, Z. Effect of water stress with phasic development on yield of wheat grown in a semi-arid environment. Field Crops Research, Amsterdam, v.5, n.1, p.55-67, 1982.

KUMAR, A.B.N.; HUNSHAL, C.S. Correlation and path coefficient analysis in durum wheats (Triticum durum Desf.) under different planting dates. Crop Research Hisar, v.16, n.3, p.358361, 1998.
MCMASTER, G.C. et al. Irrigation and culm contribution to yield and yield components of winter wheat. Agronomy Journal, Madison, v.86, n.6, p.1123-1127, 1984.

SAS INSTITUTE INC. SAS - Procedures Guide; version 6. 3.ed. Cary : SAS Institute, 1990. 705p.

SHAMSUDDIN, A.K.M. Path analysis in bread wheat. Indian Journal of Agricultural Sciences, New Delhi, v.57, n.1, p.4749, 1987.

SIDWELL, R.J. et al. Inheritance and interrelationships of grain yield and selected yield related traits in a hard red winter wheat cross. Crop Science, Madison, v.16, n.5, p.650-654, 1976.

SIMANE, B. et al. Ontogenetic analysis of yields components and yield stability of durum wheat in water-limited environments. Euphytica, Dordrecht, v.71, n.3, p.211-219, 1993.

SIMANE, B. et al. Growth and yield component analysis of durum wheat as an index of selection to terminal moisture stress. Tropical Agriculture, Guildford, v.75, n.3, p.363-368, 1998.

SINGH, D. et al. Correlation and path coefficient analysis among flag leaf area, yield and yield attributes in wheat (Triticum aestivum L.). Cereal Research Communications, Szeged, v.7, p.145-152, 1979.

THOMPSON, J.A.; CHASE, D.L. Effect of limited irrigation on growth and yield of a semi-dwarf wheat in southern new south wales. Australian Journal of Experimental Agriculture, East Melbourne, v.32, p.725-730, 1992. 